Article

\title{
Exploring the Relationship between Leisure and Sustainability in a Chinese Hollow Village
}

\author{
Lijun Zhou ${ }^{1, *}$, Lucen Liu ${ }^{1}$, Yan Wang ${ }^{1}$, Yuxian $\mathrm{Ou}^{1}{ }^{\text {and Zijing Zhao }}{ }^{2}$ \\ 1 College of Education, Zhejiang University, Hangzhou 310058, China; lucenliu@icloud.com (L.L.); \\ wy19940903@gmail.com (Y.W.); eveqiya@163.com (Y.O.) \\ 2 School of International Studies, Zhejiang University, Hangzhou 310058, China; tinazhao0328@hotmail.com \\ * Correspondence: janezhou328@zju.edu.cn
}

\section{check for} updates

Citation: Zhou, L.; Liu, L.; Wang, Y.; Ou, Y.; Zhao, Z. Exploring the Relationship between Leisure and Sustainability in a Chinese Hollow Village. Sustainability 2021, 13, 10031. https://doi.org/10.3390/su131810031

Received: 9 August 2021

Accepted: 3 September 2021

Published: 7 September 2021

Publisher's Note: MDPI stays neutral with regard to jurisdictional claims in published maps and institutional affiliations.

Copyright: (C) 2021 by the authors. Licensee MDPI, Basel, Switzerland. This article is an open access article distributed under the terms and conditions of the Creative Commons Attribution (CC BY) license (https:// creativecommons.org/licenses/by/ $4.0 /)$.

\begin{abstract}
This study explores the relationship between a for-profit leisure program and sustainability issues in the context of a hollow village in China. We studied what forms of relation between leisure and sustainability could be identified through the operation of 'Mount Qi and the hermit master' at a hollow village, and to what extent, 'Mount Qi and the hermit master' can be considered as a sustainable leisure program. Fieldwork and focus groups were used to collect data. Theoretically, the analyses adopt a comprehensive model of sustainability, which integrates the concepts of weak and strong sustainability, as well as considers the sustainability of human needs. Our findings demonstrate that the leisure program has contributed to a comprehensive sustainable development and helped to meet the villagers' needs. This study also critically points out the uncertain aspects relating to the sustainability of human needs at the current stage of the program implementation.
\end{abstract}

Keywords: China; ecology; leisure; hollow village; human needs; martial arts; sustainability

\section{Introduction}

Since the 1990s, industrialization and urbanization have transformed the landscapes of China, as well as the population mobility in the country. Such development created the phenomenon of hollow villages in China, which was an inevitable trend and a continuing challenge to the sustainable social, economic and ecological development for China [1]. The phenomenon of hollow village is not only visible from the emptiness of rural houses and areas, but also in the mass flight of the young and middle-aged labor force from the villages. Compared with family migration in the West, Chinese rural family migration mostly was due to the young male adults leaving for the cities and hence, the majority of the remaining population in the rural are elderly, women and children [2]. With less labor in the rural areas, a series of social and ecological implications occurred, such as family separation, weakened parent-child relations, ageing in the villages, environmental degradation and the reduction of agricultural production. Hence, the central government issued policies aiming to transform this situation and revitalize the rural areas [3].

In line with the concern of the sustainable development in the rural China, this paper explores the relation between a leisure program and sustainability issues in the context of a hollow village in China. We selected a newly developed for-profit leisure program at a local hollow village, due to its potential of sustainable impact in the village. This leisure program is named 'Mount Qi and the hermit master', designed and operated by a private company. This leisure program mainly consists of martial arts practices, recreational agricultural activities and rural tourism. This paper offers empirical evidence to the interplay of leisure and sustainability, which is an under-explored intersectional area by both leisure and sustainability studies [4]. Regarding the relationship between leisure and sustainability, leisure can have both positive and negative impacts on issues of sustainability, such as the natural and urban environment, economy, social equity, and consumptive behaviors [5-7]. We asked: what forms of relationship between leisure and sustainability could be identified 
through the operation of 'Mount Qi and the hermit master' at a hollow village, and to what extent can 'Mount Qi and the hermit master' be considered as a sustainable leisure program?

Since in the field of leisure study, "there is a need for more explicit links between leisure and sustainability in the literature" [4] (p. 297), this study has the potential to contribute to strengthening this link.

\subsection{The relation between Leisure and Sustainability}

Leisure is a complex concept to define, since it is associated with time, space, and human activities, experiences and emotion [8-11]. The most common understandings of leisure are based on the opposition to work, either paid or non-paid jobs or domestic chores. However, scholars argue that there are blurred lines between work and leisure [12-14] and leisure is culture- and context-specific [15], which increases the difficulty in precisely describing the nature of leisure. In this study, we did not go as far as to the philosophical discussion of leisure (e.g., [16]), but use a broad and common-sense understanding of leisure, such as playing, touring, sporting, eating, drinking and other entertaining and recreational practices for the sake of intuitive self-pleasure [17]. This understanding of leisure could be found in most of the empirical studies of leisure and in the 'Mount Qi and the hermit master' program.

A recent systematic review on the relation between leisure and sustainability found that there was very few research that has developed explicit links between these two topics [4]. Vaugeois et al. [4] summarized three dimensions of sustainability that prior leisure research has covered, namely the socio-cultural, environmental and economic sustainability. Among these three dimensions, leisure scholars have contributed most to the understanding of environmental sustainability $[4,18]$. This point is also reflected from the emerging area of sport ecology, which has a focus on environmental sustainability [19-24]. The second dimension that leisure scholars studied most is the area of socio-cultural sustainability, while the economic dimension of sustainability was examined the least in the prior research [4]. For this study, not only will we cover the three dimensions, but also explore the interdependency of these dimensions.

The well-known definition of sustainability can be found in the Brundtland Report, as the "development that meets the needs of the present without compromising the ability of future generations to meet their own needs" [25] (p. 41). Accompanying this definition, there are two major concerns around the 'needs' that are "the needs of the world's poor" and "the environment's ability to meet present and future human needs" [25] (p. 42). These two needs from the definition of sustainability were rarely addressed in the extant research, which mainly covered the three dimensions of sustainability. This study is highly relevant to 'the needs of the world's poor' and 'the environment's ability to meet present and future human needs', as the context of the leisure practices in this study is in a hollow village.

\subsection{The Phenomena of Hollow Villages in China}

To better understand the context of the leisure program that we attempted to study, we introduce the phenomena of hollow villages in China, which have faced varied unsustainable problems. Since the early 1990s, the phenomena of hollow villages appeared in China, due to the influences of industrialization and urbanization on rural areas [26,27]. Hollow villages are commonly seen in the rural areas of China, and are the result of a large number of young rural workers migrating to the urban areas, leaving the elders and children and creating abandoned houses and agricultural land in the villages [26,28]. Scholars have summarized three major problems of hollow villages [26,27,29-32]. First, the loss and waste of agricultural land created a crucial environmental problem. Second, the agricultural land loss led to the deterioration of the environment, its habitability and the quality of human settlements. Third, hollow villages endangered rural life, widened the economic and social gap between urban and rural areas, and may lead to social instability. These issues associated with hollow villages reflected unsustainable problems, such as 
around "land, population, economy, society and culture" [26]. Hence, the Chinese government has issued a series of policy documents to support the economic development and revitalization of the rural areas and attract young people to return and live and work in the villages [3]. For instance, in the latest policy "Opinions on Comprehensive Revitalization of the Rural and The Acceleration of Modernization in the Rural Agricultural Sector" [33], the government encourages the practice of green agriculture, the construction of infrastructure, and the provision of public education and medical services in rural areas. More crucially, to sustain the revitalization of rural areas, the government attempts to increase the twoway mobility of humans and capital between urban and rural areas. Through the leisure program analyzed in this study we can explore the methods of sustainable revitalization at the hollow village.

\section{Theoretical Framework: A Comprehensive Model of Sustainability}

In this section, we first review the traditional dual approaches, weak and strong sustainability. Following that review, we then introduce the conceptual framework and the comprehensive model that have the potential to merge the binary approaches which we propose to use in this study.

\subsection{The Dual Model: Weak and Strong Sustainability}

Sustainability and sustainable development are important concepts of "integrating social, economic and ecological dimensions of development and jointly addressing objectives conservation and change" [34] (p. 1120). Sustainability relates to the contexts of economic growth and nature conservation. These two areas have been excluded in the extant literature, resulting in mutually exclusive concepts of 'weak' and 'strong' sustainability [34].

Traditionally, the weak approach of sustainability is grounded in the neoclassical capital theory, which adopts a human-centered view and treats the natural resources as replaceable by mankind-manufactured capital [35]. In this view, sustainable development can be achieved as long as the total amount of capital increases in the process of development, even if the natural capital was consumed to "an unrecoverable state, it is still sustainable" [35] (p. 7). The weak approach of sustainability focuses on general production capacity and economic increase; even if natural non-renewable resources are exhausted and the environment is polluted in the process, as long as enough human-made capital is aggregated, this compensates for the decrease of natural resources [36].

In contrast to the weak approach of sustainability, strong sustainability adopts a naturecentered view, which regards that natural capital is non-substitutable and irreplaceable and claims that the natural environment and its capacities and functions should remain constant or even intact over time $[34,36]$. As human manufactured capital depends on the input of natural resources, the process of sustainable development should not exceed the ecological limits, which can be measured by the laws of environment, such as the physical properties of biocapacity [34,35].

\subsection{A comprehensive Model: Combining the Weak and Strong Sustainability}

Scholars have pointed out that the traditional 'weak' and 'strong', or 'human-centered' and 'nature-centered' approaches of sustainability have positioned the ecosystem and human society as separate domains which have different goals [37]. However, there could be overlapping interests and mutual concerns in these two perspectives of sustainability. To overcome this binary and go beyond the debates favoring economic development or environmental conservation, alternative conceptual frameworks were proposed, such as the "integrated approach" [34] (p. 1121), the "pragmatic middle view" [37] (p. 382) and the aggregate approach [38]. In this paper, we adopt and propose to use a comprehensive model of sustainability based on Jenkins' [37] conceptualization of pragmatic approaches towards sustainability, the Chinese philosophical concept of the unity of nature and man, and Sen's [39] freedom and needs-oriented view on sustainability. 
Jenkins [37] argued that "the concept of sustainability frames the ways in which environmental problems jeopardize the conditions of healthy economic, ecological, and social systems" (p. 380). However, the ecological, economic and social aspects of sustainability can be mutually supportive (see Figure 1). The Chinese philosophical concept of the unity of nature and man also inspired us to view the interdependence between human society and the natural environment. The unity of nature and man states the harmonious relationship between nature and man, which can inform the construction of a comprehensive model of sustainability. The diagram below shows a relatively comprehensive model of sustainability, which contains three dimensions, economic, ecological and socio-cultural, to analyze the sustainable development that the leisure program brought to the village.

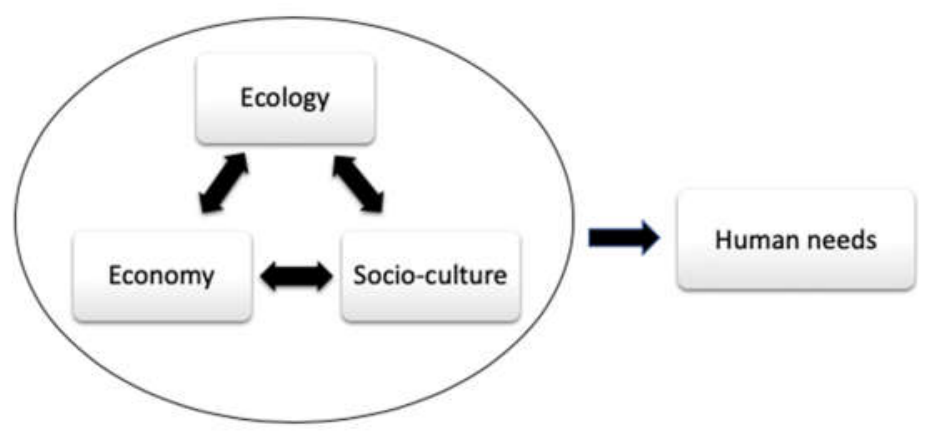

Figure 1. A comprehensive framework of sustainability and the needs-oriented goal.

From this model, economic and socio-cultural sustainability rely on ecological systems. Both ecological and economic development could result in socio-cultural benefits. At the same time, nature needs to be modified to meet the social, economic, and cultural needs [40]. The belief of the unity of nature and man is by no means returning to a primitive lifestyle, and in contemporary times, it means to have productive dialogues with nature [40]. Having a productive dialogue with nature can allow humans to live a decent life, meaning maintaining a healthy natural environment, as well as ending extreme poverty [37]. This comprehensive model does not view the ecological, economic and sociocultural goals as distinct or separated, but recognizes their mutual relation and encourages practices to find ways to address the interrelated goals.

This model also considers the human needs, which are two intertwining concepts. Sen [39] argued that "human freedoms include the fulfilment of needs, but also the liberty to define and pursue our own goals, objectives and commitments, no matter how they link with our own particular needs" (p. 6). The consideration of human needs is associated with the social justice in sustainable development. On one hand, sustainable development needs to meet the "basic needs of all and extending to all the opportunity to satisfy their aspirations for a better life" [25] (p. 42), and on the other hand, it needs to prioritize the needs of the poor, when we strike a balance to meet the present and future generations' needs [25]. Hence, this comprehensive model of sustainability is both inclusive and "ambiguous", because it adds moral and social justice considerations into the relatively quantifiable ecological and economic development [37] (p. 381). Later in this paper, we employ this model to analyze the case of the leisure program and explore to what extent it has balanced a comprehensive sustainable development.

\section{The Research Context: The Tea Village and the Leisure Program}

Tea Village is located in a Mountain National Reserve in the southwest of Zhejiang Province, China (see Figure 2). Local government officials pointed out that there are numerous villages like Tea Village scattered throughout this remote area far from the major cities in the province (see Figure 3). The 400-year-old Tea Village has about 140 registered villagers, but the resident population was only around 30 at the time of the study and 
mostly were elderly people. There were almost no left-behind children, as they left with their parents to larger towns nearby.

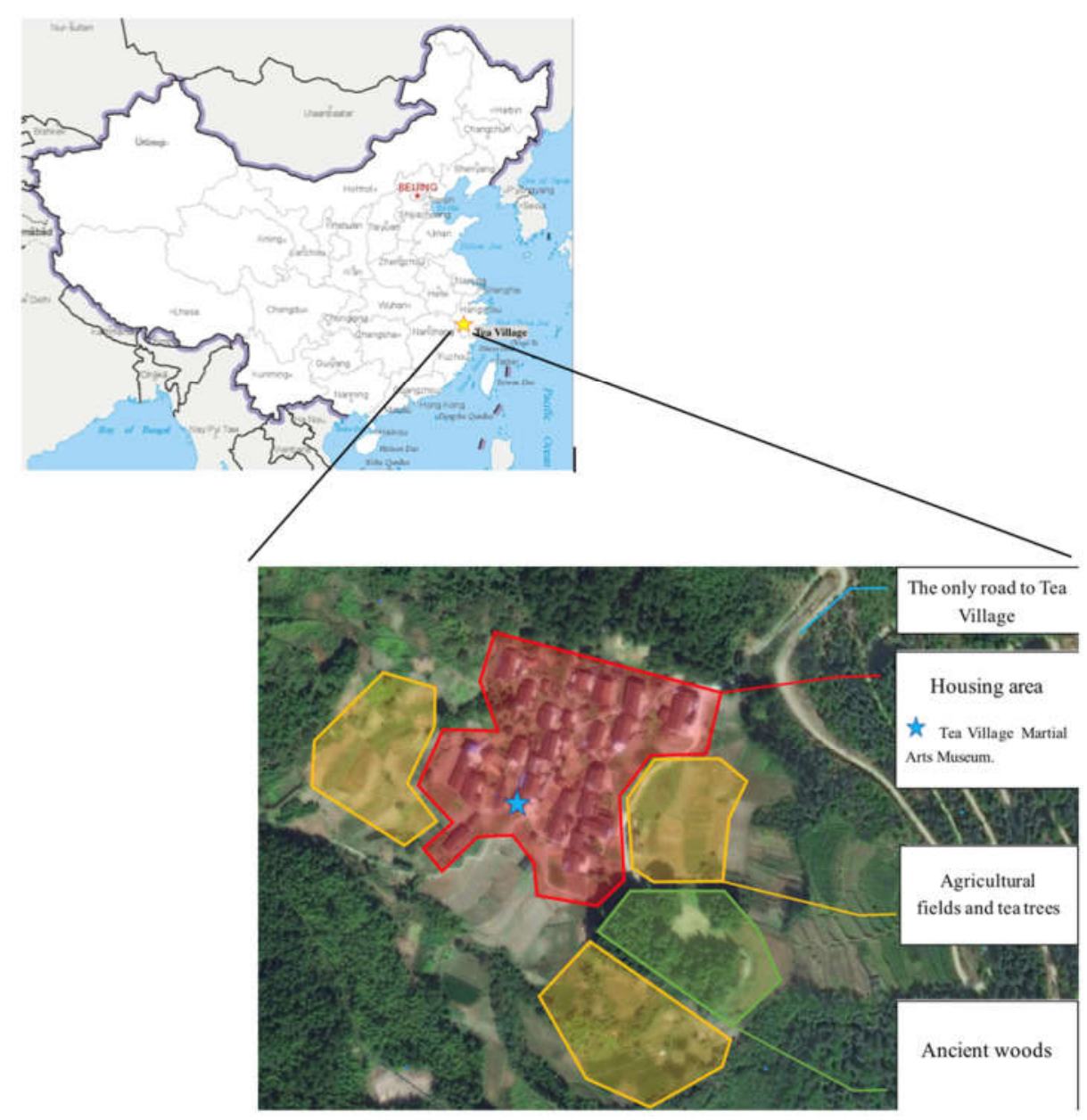

Figure 2. The location of the Tea Village in China.
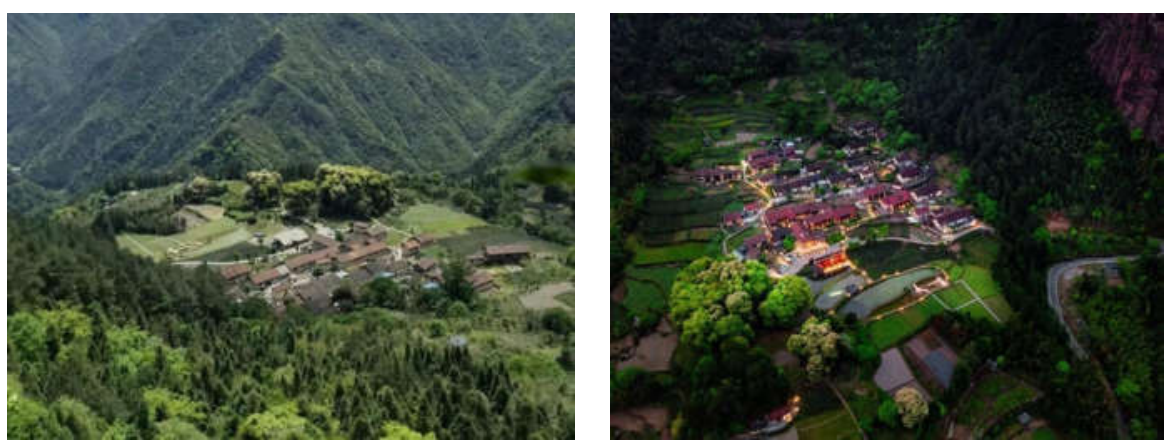

Figure 3. Bird's eye view of the Tea Village. Source: https://mp.weixin.qq.com/s/Kv0ONX21CY5 xTWiVpbgAyQ (accessed on 20 May 2021).

In 2007, the village was well-known by people because its martial arts were recognized as its intangible cultural heritage. The village's traditional martial arts have 280 years of history and have been handed down through 11 generations. The village's martial arts have seven sets of moves, including three sets of boxing moves, three sets of stick-fighting moves and one set of spear-fighting moves. These seven sets of moves are varied, explosive and quick. They are easy to learn, but hard to master. Male villagers used to practice the traditional martial arts to defend against bandits and to guard the peace of their families. 
In current times, martial arts practices can be taught to both male and female villagers and are practiced for the health benefits.

The year 2016 became a watershed year for the village, when the owner of Le Living company first visited the village. The company has developed various community-based leisure programs in different rural areas and towns in China. The company owner noticed the intact traditional mud houses and natural environment of the Tea Village and decided to run a martial arts themed leisure program in the village to attract urban residents to come relax and experience the traditional village life. A family normally has two to three houses and/or huts, which are used for living, cooking, or storage. At the end of the year 2016, the company signed contracts with villagers to rent their old mud houses for twenty years, as well as to renovate the interior space into boutique homes or villas. After 20 years, these houses will be returned to villagers and the villagers can choose to renew the lease or take their houses back.

In 2019, the leisure program officially opened 14 villas and each was named after the titles of Kung Fu novels by Jin Yong (also known as Louis Cha or Cha Leung-yung) to reflect the village's martial arts tradition. The village itself is free and open for people to visit, but to stay at the villas and participate the activities, which will be introduced and discussed later, one needs to be a paid member. The program employs about 30 staff and many of them are villagers, who received a monthly payment from CNY 2000 to 3000 . By the end of 2019, the resident population of the villages had raised to 87 and the per capita income of villagers had increased by more than $200 \%$ compared to the year before.

\section{Methods}

\subsection{Data Collection}

We employed two methods to collect data, fieldwork, including participant observation, and focus group interviews. The purpose of the fieldwork was to be familiar with the context of the village and the leisure program, as well as to meet and invite the company owner, the program managers and employees, and the villagers to be the research participants. Thereafter, the interview process expanded upon our initial observation in the field and interactions with the program staff and the villagers.

\subsubsection{Fieldwork}

We came to know this village and the leisure program when we were helping the local government to plan their future outdoor leisure development. With the prior knowledge of the village and the program, and the permission from the company owner, some employees and villagers, we conducted two-day fieldwork at the village to gain firsthand and deeper understanding of the complex and multifaceted relationships between leisure and sustainability. Fieldwork is widely used to investigate the development and tourism in rural areas in China $[18,41,42]$ as a way to allow the researchers to 'be there' and gain direct and holistic views of the real context. In the field, we mainly used the methods of participant observation, including taking fieldnotes, photographing and filming, to record the activities in which we participated. The activities included staying at a villa, joining martial arts practices and green tea making processes, and visiting the agricultural fields, the ancient woods, the martial arts practicing field, a martial arts museum and a villager's renovated home. Our roles in the field varied between participant-as-observer and observer-as-participant [43], depending on the activities and settings we were in. For example, during the fieldwork, we helped in picking fresh tea leaves and fixing the leaves, but we observed the villagers hand kneading and rolling the leaf into balls, scattering the leaf on large round bamboo trays and storing them on shelves for drying and oxidizing. Regarding martial arts practices, we joined the warming up before the villagers and program staff martial arts practices and then we photographed and filmed them practicing different sets of martial arts moves. Textual data, such as fieldnotes and researchers' reflections, and visual data, such as photos and video clips, were created by researchers. 


\subsubsection{Focus Group Interviews}

During the fieldwork, we conducted two focus group interviews, involving 9 participants in total (see Table 1).

Table 1. Details of two focus groups.

\begin{tabular}{ccccc}
\hline & Dates & Duration & Participants & Number of Participants \\
\hline Focus Group 1 & $\begin{array}{c}\text { On the first day of } \\
\text { the fieldwork } \\
\text { Focus Group 2 }\end{array}$ & $\begin{array}{c}\text { On the second day of } \\
\text { the fieldwork }\end{array}$ & $60.57 \mathrm{~min}$ & $\begin{array}{c}\text { The company owner and 2 } \\
\text { program managers } \\
\text { 1 employee-nonvillager, 2 } \\
\text { employee-villagers and 3 } \\
\text { nonemployee- villagers }\end{array}$ \\
\hline
\end{tabular}

Focus groups are an efficient approach to collect interactive data from working people and can initiate discussion among participants [44]. Focus Group 1 included key company personnel, who are positioned at relatively senior managerial levels. To avoid participants concern of hierarchical power relationships, Focus Group 2 only invited intermediate- and junior-level staff. These participants, from different levels at work, had varied experiences of living and working in the village. The interview guides were designed to encourage discussion on our initial observation around the ecological, economic, socio-cultural features in the program. During the focus groups, we ensured that each participant was asked the same set of questions, which enabled them to lead the conversations and elaborate their experiences of the program and/or how their life and the village have changed. With Focus Group 1, the company owner (male) and two program managers (females) were asked about their encounter with the village, the ideas and the design concept behind this leisure program, their work and their interactions with the villagers, their views on the village's surrounding environment, and the martial arts tradition. With Focus Group 2, we asked the 3 program employees (males) and 3 nonemployee villagers ( 2 males, 1 female) about their experience of practicing martial arts, working in the program, life in the village before and after the program was implemented, and the history of the ancient woods and martial arts tradition. The focus group interviews were recorded using a recording app on a smart phone and all audio recordings were transcribed verbatim by researchers.

\subsubsection{Data Analysis}

Data was analyzed following Braun and Clarke's [45] six steps of thematic analysis and Clarke and Braun's [46] emphasis on theory-driven thematic analysis. First, we familiarized ourselves with the textual data, including the fieldnotes, self-reflections, and focus group transcripts. Second, we used a deductive method to code the texts and produced the initial framework-driven codes, such as sustainable agricultural practice and economic growth. Third, the related codes were grouped together based on the different dimensions in the comprehensive model of sustainability. Fourth, we searched for the shared meanings in the grouped codes and generated initial themes. In the fifth step, we repeated the third and fourth steps to review codes and themes and found that some groups of codes were interrelated and hence, led to the generation of interrelated themes. Then, we renamed and refined three themes and produce the report. Below we discuss the three themes that help to address the research questions: what forms of relation between leisure and sustainability could be identified through the leisure program operated at a hollow village, and to what extent can the program can be considered as a sustainable leisure program?

\section{Findings}

5.1. Ecological, Economic and Socio-Cultural Aspects of Sustainability through the Program's Recreational Agricultural Activities

The leisure program relies on the natural environment, while, at the same time, the efforts to sustain ecology could be seen in the program. The operation of this program 
reflected the strong sustainability means of protecting natural resources, but somehow met the weak sustainability end of economic increase.

When this program was designed, the natural environment was a major attraction for the company. The company owner reflected on the reason to choose this village, as he described his impression of the surroundings of the village:

Just have a glance outside. The advantage of it (the ecological aspect) is obvious. I first came here at the end of 2016 and a few days ago, the local officials have taken me to see other places, one village after another. On the way here, we drove through mountainous areas and the roads were not good, so no factories and industries, but that protected the entire ecology, natural environment, the mountain and its vegetation. ... All along the way, I've been in such scene: a long road, on one side, is a stream and on the other side is the mountain.

In the village, adjacent to the housing area, there is a patch of ancient woods with about 80 trees (see Figure 4), which is considered the most valuable resource for the company and the villagers. The company owner pointed out that:

When I came here, what struck me most about this village was the ancient woods. ... I found that when I stood in these woods, I felt I was breathing through, living in and surrounded by thousands of years of time and space. I don't know how to measure the value with money and how to evaluate its price. I think those elites who live in cities would understand the value of it.
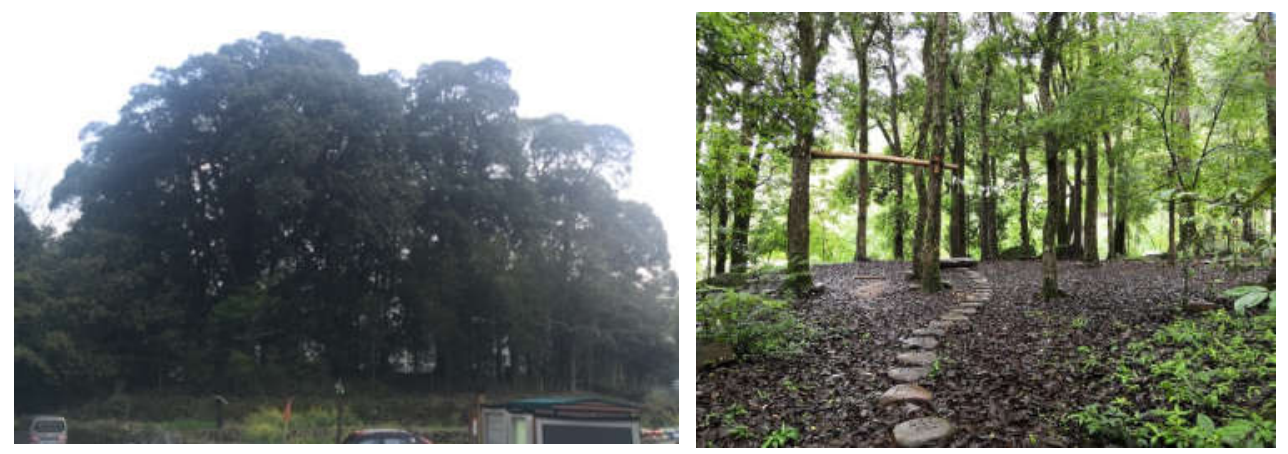

Figure 4. The ancient woods and the martial arts training field inside the woods.

The ecological aspect of sustainability in this program echoes the nature-centered strong sustainability, which can be seen more from the villagers' narratives. According to villagers, the ancient woods which existed long before their ancestors migrated to this area are historically and spiritually meaningful for them. Nonemployee villager 1 said: "Forestry experts came to examine these trees and thought they are more than 400 years old". There is a story in the village about these ancient woods, which illustrates the significance of the trees for the village, spatially and spiritually. Employee-villager 1 said:

Once, there's a pine tree in the middle of the woods. The pine was bigger and taller than other trees. It was a village bully, who cut the pine down and sold it. Afterwards, something very dangerous happened here. A plague hit our village and nine out of the 11 or 12 children died. ... we are still calling this patch of ancient trees-the Pine Woods. We think our ancient trees cannot be moved or cut. If any of these ancient trees die, unfortunate events would occur in the village. We truly think that way. That's why the ancient woods could be protected. Now, no one dares to harm the trees. It's really powerful and spiritual.

The ancient woods are a crucial part of the village's martial arts tradition, since the martial arts training field is located inside this patch of ancient woods. At the center of the woods, there is a clearing ground about 100 square meters.

Employee-villager 1, the male leader of village martial arts team, said, "we used to practice in the middle of our ancient woods, because there're a lot of spaces in the woods. 
We used to train on the plum blossom piles (an arrangement of wooden poles sunk into the ground) in the woods. Hence, due to the business value of the woods as well as the respect for the villagers' belief, the company protected ancient forests when developing the program. The protection reveals strong sustainability, keeping the woods intact."

When the program was renovating the houses, the vegetable fields, melon sheds and fish ponds around the houses were kept. In addition, in a 60-acre wasteland, the program staff grew herbs used in traditional Chinese medicine and kiwi fruits and planted fruit trees. This all being said, the operation of the program also aligns with the essence of weak sustainability shown in the evidence below.

The weak sustainability reflected from the program's economic gain from repairing and restoring the agricultural land. Program managers 1 and 2 developed agricultural programs attributable to the growth in revenue. Program manager 1 said:

Last year we designed a program called 'Spring Ploughing'. Villagers helped to grow corns, rape seed flowers, rice and other things (in the company rented agricultural land) and send our members living in cities the agricultural products, such as cornmeal, vegetable oil, chestnuts, dry vegetables.

Program manager 2 added that:

This year we upgraded the program and named it 'the Dining Plan'. Our members in the cities wanted to eat seasonal food, so we sent them free-ranged chickens and eggs during the Chinese New Year. In March, we sent them spring bamboo shoots. Now we are making green tea and vegetable oil to send to them.

The village's relatively unpolluted natural environment and the program's organic products were favored by the program's urban-residing members, which echoes to a prior study finding that urban Chinese dwellers have a tendency to consume organic and unpolluted foods from the rural areas [18]. Employee-nonvillager 1 explained that "those members who had been here really enjoyed the village and the air, water and ecology, so they feel safe to eat the agricultural products from here". From an ecological perspective, the previous unplanted agricultural land in the village was actually destroying the cultivated soil, in terms of losing mineral nutrients and decreasing soil function $[26,27,47,48]$. Even though the agricultural products can increase the company's revenue, the company did not over-farm or over-develop the land. The leisure program not only relies on but also aims to retain the original look of the village. As the company owner said:

You can see the village's original texture and its ecological way of life haven't been changed. When we first came to the village, the houses were a little shabby and some walls were collapsed, we only did the minimum repair of the walls, so the original look of the village was retained. It's still a typical small mountain village in this area and we think this's very valuable.

From the evidence, we can see a sustainable natural environment and economic increase can be interdependent, rather than mutually exclusive. For this program, protecting the natural environment and reviving agricultural capability can be regarded as a means to an end-economic benefits.

\subsection{Economic, Socio-Cultural and Ecological Aspects of Sustainability through Program's Promotion of the Traditional Martial Arts}

The economic sustainability in the hollow village was motivated by the nature of this leisure program in that is a business program, which generates a profit for the company and provides the employee-villagers with income. The program used a martial arts relevant concept, 'the hermit master', as the core driving force to operate their business model. To create the feelings of seclusion, the preservation of natural environment was crucially important. Hence, the economic aspect of sustainability is related to the ecological aspect of sustainability discussed in the above section. Even at the early stage, the company conceived a multi-dimensional model to guide their business operation in the village, as the company owner said. The company's investment into martial arts and the agricultural 
products as mentioned above not only constructed the multi-dimensional business model, but also can be regarded as creating economic sustainability in the village. This section mainly discusses the economic aspect that invests in the village's martial arts traditions.

There are four types of investments that the company made regarding Tea Village martial arts. First, a Tea Village Martial Arts Museum was built to showcase the history, heritage and representative figures of this style of martial arts (see Figure 5). From our interviews, male villagers said they normally started to learn the martial arts moves at a very young age, 5 or 6 years old, from their father and grandfather or other elder male villagers. Villager 2 said: "When adults went to practice martial arts, I followed them and imitated their moves. It's like playing game. Later, when I started to learn it, I needed to get up very early and went with my father to the training ground, where was behind the Museum. In the old days, at the location of the Museum was a big barn and the villagers could gather inside and practice." The newly built Museum stood at the old training ground and also has space big enough for group marital arts practices.

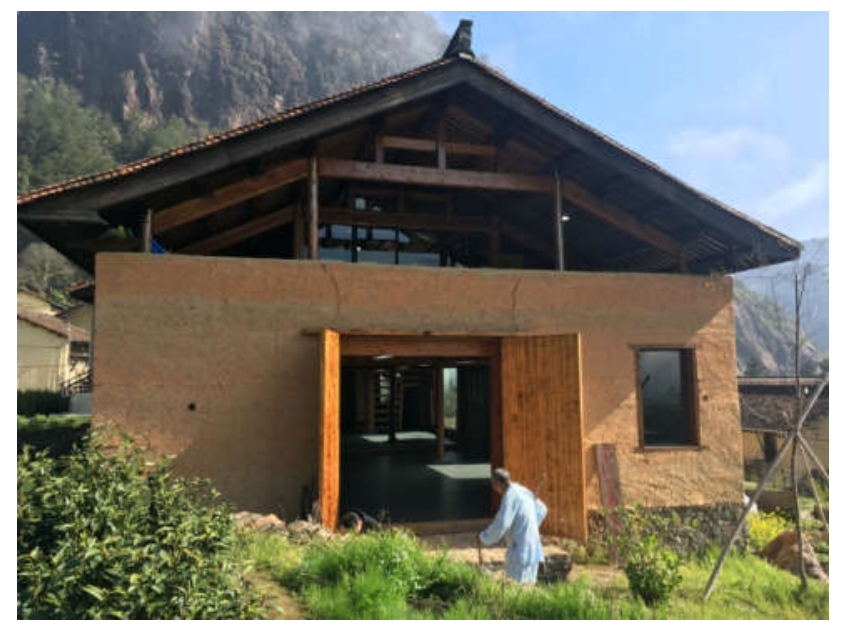

Figure 5. A newly built Tea Village Martial Arts Museum.

Second, the renovated villas were named after the titles of Jin Yong's Kung Fu novels. Different villas were assigned with the novel titles based on their different features and to increase the martial arts atmosphere in the village and attract visitors. Inside the villas, there are martial arts costumes to cosplay the characters in Jin Yong's Kung Fu novels and adapted films. Cultural and creative souvenirs of the martial arts are there as well, such as creative t-shirts with martial arts designs. The company's investment around the martial arts, such as the construction of the museum and villas, and souvenirs, reflected the interplay of both economic and cultural sides of sustainability.

Third, in 2017, the company cleared a field beside the ancient woods to be the new open space for practicing martial arts. The two new spaces of martial arts practicing, the museum and the open space, can help to protect the ancient woods. New plum blossom piles, for training the steps, were set up in the open space (see Figure 6).

Fourth, the program organizes morning martial arts practices, and it has become a routine in the village. Every morning, around 8 am, employees and villagers gather in the open space beside the ancient woods to learn and practice together (see Figure 7). This morning exercise can be regarded as an investment in the sustainability of villagers and company employees' health and wellbeing. 


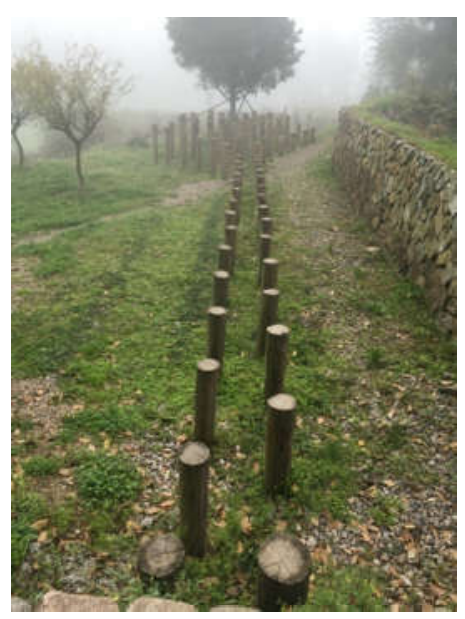

Figure 6. New plum blossom piles in the open space.
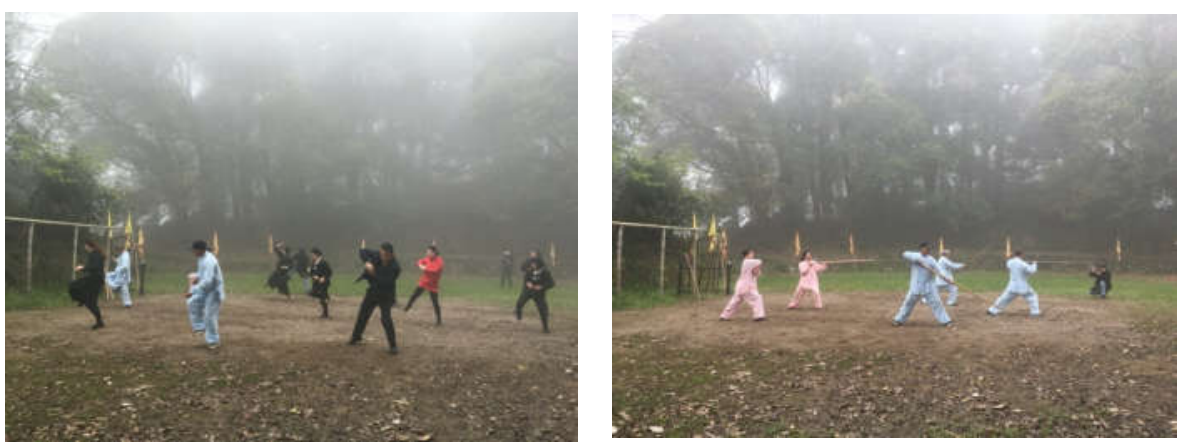

Figure 7. Early morning martial arts practices by the program staff and villagers.

The company's four types of investment into the village's martial arts are in line with the villagers' aspiration of preserving their traditions. Nonemployee-villagers 1 and 2 stressed that:

Nonemployee-villager 1: My father was a famous martial arts master in this village. He used to tell me we must pass down our martial arts and my village has been always like that. We take ancestral teachings and ways of doing things seriously. Our ancestors said the Luo family's staff fighting techniques must be passed down and my father said to me I could forget about everything except our martial arts, especially the staff fighting techniques.

Nonemployee-villager 2: My great grandfather said the same. He told us we shouldn't let our martial arts disappear. We must hand it down to the next generation.

Moreover, the company's martial arts focused business model expanded the demographics of the martial arts learners. This not only sustained the village's martial arts tradition, but also changed the tradition into modern-time practices. As Employee-villager 1 , the female leader of village martial arts team, recalled:

In the past, when the village wasn't busy with farming, we would all gather together to learn martial arts. We also practiced with the 24 solar terms, and especially on the day of the Lunar New Year, the whole village practiced together. Unlike nowadays, in the past, martial arts training was very harsh. And only passed down to men, not to women. The girls in the village weren't allowed to practice.

After the company came to the village, martial arts were taught to everyone, regardless of their gender and origin. Employee-villager 1 said:

It's changed, not like before. We all learn and practice (martial arts) together. Old folks were concerned and told us not to teach everything we know to outsiders. They were 
afraid that people from outside learn everything we know and the martial arts wouldn't?? be ours. The old folks still have such concerns and constantly came to us to say what we can and can't teach to outsiders.

The company facilitated the modern twist of the village's martial arts tradition. Employee-villager 2 is the leader of the village's female martial arts team and said, "I was married into this village and saw everyone practicing martial arts, even those who are eighty or ninety years old. I saw everyone's practicing, so I follow them to learn". Nonemployee-villager 2 affirmed that:

I think we shouldn't only teach our own people. If people from outside came to learn, we also should teach them. Especially now, martial arts are integrated into sports and can help to build up physical fitness. Now we need to spread the essence of our martial arts to other places, even though our ancestors made the rules of not teaching women, but those're outdated ideas. Now people are more open-minded and want to be healthier and fitter through martial arts practices. I wish our martial arts can be learned by more and more people.

The company's business model around martial arts could help to promote what Nonemployee-villager 1 envisioned. By keeping and promoting the martial arts, the village has attracted visitors, increasing the economic development and revive the village life. The revival of Tea Village's martial arts was noticed by the local government and in a recent marathon race earlier this year, some villagers were invited to perform their martial arts to the marathon runners (see Figure 8).

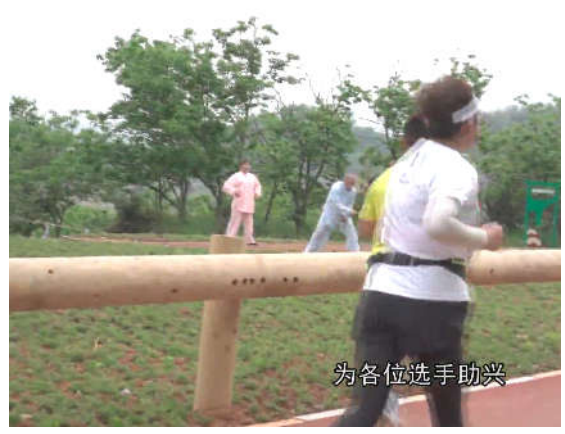

Figure 8. Some villagers were invited to perform at a local half marathon race to cheer for the competitors. Source: https://mp.weixin.qq.com/s/vsj42dcfgpzxlqkhpgg8uw (accessed on 20 May 2021).

\subsection{The Comprehensive Sustainability and the Needs of the Villagers}

In this section, we discuss the impact of the comprehensive model of sustainability on human needs. The evidence showed that the program's integrated sustainable dimensions, namely the ecological, economic and socio-cultural aspects, had the capability to enhance human needs that villagers valued. From the analysis, we found that the affirmation of the village life and the restoration of confidence are the two results from the needs-oriented view of sustainability (see Figure 9).

Regarding the affirmation of the village life, the company made efforts in protecting the ancient woods, repairing the farmland, renovating the villas and promoting the martial arts. As discussed above, these efforts mutually increased the ecological, economic and cultural sustainability of the village. Instead of excluding or subordinating the villagers or even worsening the poor condition of local life, the leisure program development in the village has empowered the villagers and boosted the confidence of villagers. 


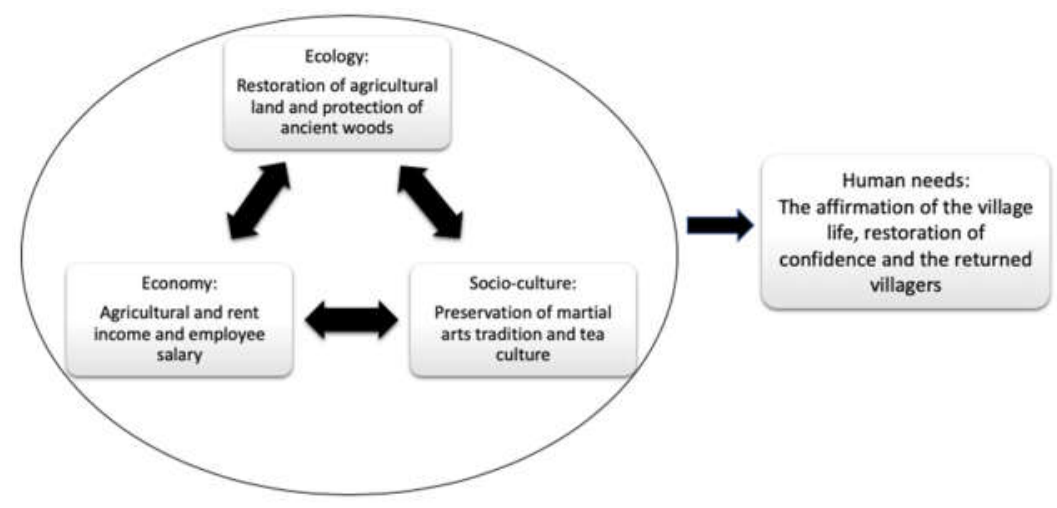

Figure 9. The three dimensions of sustainability and the needs-oriented goals.

The protected ecological environment serves as a background or foundation to support the village life, which was highly appreciated by the program guests. As Employee-villager 1 said:

The guests would have meals and activities at there (the ancient woods). We all gathered there. The guests especially loved to be there and they played erhu and flute in the woods.

They also sat there having afternoon tea. Some of them also practice Kung Fu swords there.

Through sharing the way of village life, the ancient woods have been protected and the martial arts tradition been promoted.

The economic aspect of sustainability was embedded in the affirmation of village life. Employee-villager 1 pointed out that the leisure program included the villagers from the beginning, rather than excluding them. Employee-villager 1 explained the economic benefits that the leisure program brought to the villagers. The program has increased their income through three ways; the rent of their houses, the rent of their land, and the wages for working in the leisure program.

The socio-cultural aspect of sustainability embedded in the leisure program's advocates 'living with the locals' and the equal relationship between urban guests and villagers. The company owner recalled that when they first expressed their attempt to keep the exterior of old mud houses, the villagers who own the houses did not favor the company's plan, because they wanted us to rebuild the wall using concrete and decorate the wall with white tiles. To make compromises, the program designed and built modest looking new houses beside the traditional mud houses for the owner's family to move in and live. Even though this program did not entirely operate as the villagers wished in terms of the disagreement on the exterior look of their traditional houses, we acknowledge that there are incompatible pursuits between socio-cultural sustainability and what the locals need.

The village lifestyle was also preserved through the leisure activities. For example, from the villagers, the guests learned to make tofu and glutinous rice balls from scratch and learn folk songs. The guests and villagers made dishes in the traditional oven together. As mentioned above, to increase the unity between villagers and company employees, local martial arts were adopted and practiced together every morning. By emphasizing that farming is a respectful and way of life, this leisure program empowered the villagers financially and psychologically.

The affirmation of the village life helped to restore confidence in the villagers. The company owner and the villagers identified that involvement in the program has improved villagers' confidence and self-worth. As Villager 5 said, for him, the real valuable gain was knowing the company owner and receiving support from him. "I can learn from the company owner and his knowledge is priceless. His words are full of positive attitudes and I feel motivated and mentally strong, so with him we can learn a lot". The company owner affirmed that the leisure program was a good way to rebuild villagers' self-confidence. As he said: 
The most valuable legacy of this program is not leaving villagers with renovated houses or increased income, but letting them acknowledging their way of life is as equal good to the life in the cities. At the beginning of this program or many years before this program, villagers thought their way of life was completely left behind from urban life. They didn't think their things are beautiful and valuable.

The leisure program rented and renovated the villagers' old houses for the guests to stay, and built new houses in traditional styles beside the old houses for the villagers to live in. Hence, the villagers are the owners of their old and new houses. The company owner pointed out that the villagers "felt that they are the masters and even though the guests are from the cities, they still have to live in my houses and they became confident for themselves and enthusiastic for this program".

The village's green tea production and culture was not only turned into income, but also increased the villagers' confidence. Employee-nonvillager 1 told us that guests from the major cities came to experience the steps of hand-processed green tea and after that, they ordered many boxes of green tea. To meet the orders, the program employees quickly contacted more villagers to produce green tea, which brought them substantial economic gains. The company owner pointed out that the urban elites' recognition of the village's agricultural products, such as green tea and vegetable oil, boosted villagers' confidence. The economic aspect of sustainability not only helped the villagers to maintain a decent living, but also helped them to gain dignity and respect.

The restoration can be seen from the evidence of village returnees. There are currently 16 villagers who work at the program. Among them, six are returnees. Before the leisure program came to the village, Nonemployee-villager 3 reflected that there were very few people staying at the village, about 30 people, most of whom were in their 70s and 80s, and the youngest residents were about 50 years old. Younger people moved out for work opportunities and children left for education. Hence, the village was very quiet. Employeevillager 2 and her husband took their son to stay at a nearby bigger town, where there were primary and middle schools. As she said:

We have stayed in the town for more than 20 years. Until the company and its leisure program came to the village and they started hiring people, I moved back to the village and worked at the program. I helped to clean the guest houses. I like working at the program and my husband also moved back. We both work here. Here, we have rent income, work income and our household income and life are getting much better.

The program motivated some employee-villagers in learning new skills. Program manager 1 commented on Employee-villager 2 that, "she learnt to use Excel by herself. She also learnt flower arrangement. And she used these skills at work, in room services."

Nevertheless, we also propose to scrutinize the needs-oriented sustainability critically. Since gaining profit is this leisure program's foremost concern, the different dimensions of sustainability, such as ecological, economic and socio-cultural aspects, that benefit the business and the fulfilment of the villagers' human needs is a spillover effect. To answer one of our research questions, to what extent can the the 'Mount Qi and the hermit master' leisure program be considered as a sustainable leisure program, there are three concerns that need to be considered. First, the employee-villagers are at the lowest level of job positions in the program, such as cleaning and gardening. Even though the company owner and program mangers referred them as colleagues, would they have the opportunity to be promoted to the middle or higher managerial level? Second, from a business perspective, fulfilling the villagers' certain human needs can better benefit the program's profit-oriented goals. As Sen [39] pointed out, the pursuit of human freedom and needs involves people's liberty to creatively define and pursue their own goals, in this case, not just fulfilling the program managers permitted or perceived needs. Third, the affirmation of village life came from the urban residents, who have more economical resources and higher social status. It seems that there is not a truly equal relationship between the villagers and urban guests, as the company owner said that the work opportunities provided by the leisure program are "taking them from the primary industry into the tertiary industry". Could 
the empowerment given from the people who have more power and higher social statuses actually transform into villagers' self-empowerment? These three concerns are relevant to the sustainability of human needs, but remain uncertain at this stage.

\section{Conclusions}

This study explored the relationship between leisure and sustainability, which is less examined by either leisure or sustainability studies. It explored this relationship in a specific setting, namely a hollow village in China. An integrated sustainability model, including the social, economic, and cultural aspects and the human needs, was used [38,40]. Through qualitative analysis, three main themes were generated that highlighted the possible relationship between leisure and sustainability: that the program's recreational agricultural activities and the promotion of the traditional martial arts enhanced ecological, economic, socio-cultural, and human-needs aspects of sustainability.

The findings especially demonstrated the interconnectedness between the varied dimensions of sustainability that the theoretical framework has outlined. Hence, this study shows that a sustainable natural environment, economic increase and the safeguarding of traditional cultural practices could be carried out together and form a mutually beneficial relationship. For example, the ecological sustainable practices of protecting the ancient woods and reviving agricultural land helped to sustain the ecology of the village, increase the villagers' income and hand down the tea making tradition.

In addition to the interconnectedness among the three aspects of sustainability, our comprehensive model of sustainability follows Sen's [39] freedom and needs-oriented view on sustainability and considers the fulfilment of villagers' pursuit of human needs. The evidence has shown that for-profit leisure practices can relatively alleviate economic social and ecological problems in the hollow village, such as unemployment, rural flight, the loss of cultural and historical heritage and the loss and waste of agricultural land. With the implementation of the leisure program, some villagers returned, and some expressed that they started to feel like they were not being left behind by the urban lifestyle. At this early stage of the operation of this leisure program, with limited data, the researchers need to remain critical towards the sustainable capability of the for-profit leisure program, especially around the sustainability of human needs. Similar to prior studies on the development of tourism in rural China [18,41,42], the findings of this study suggest that the power relation between the government officials and/or company owners and the village residents needs to be carefully considered, otherwise the asymmetry of power may neglect the needs of villagers and result in the failure of the project. This study suggests further studies are needed to critically investigate the impact of leisure practices on meeting marginalized or socially disadvantaged groups' present and future needs. Furthermore, longitudinal research is needed to examine sustainable development in the hollow villages in the long term.

Author Contributions: Conceptualization, L.L. and L.Z.; literature review, L.L. and Y.O.; methodology, L.L. and Y.W.; formal analysis, L.L.; writing—original draft preparation, L.L.; writing-review and editing, L.Z., L.L., Y.W., Y.O. and Z.Z.; tables and images, Y.W. and Y.O.; supervision, L.Z.; project administration, L.Z.; funding acquisition, L.Z. All authors have read and agreed to the published version of the manuscript.

Funding: This research was funded by The National Social Science Fund of China, grant number 19FTYB005.

Institutional Review Board Statement: The study was conducted according to the guidelines of the Declaration of Helsinki, was approved by the Ethics Committee at Department of Psychology and Behavioural Sciences, Zhejiang University by 25 February 2021.

Informed Consent Statement: Informed consent was obtained from all subjects involved in the study. 
Data Availability Statement: No new data were created or analyzed in this study. Data sharing is not applicable to this article.

Acknowledgments: The authors would like to thank the leisure program staff and the villagers.

Conflicts of Interest: The authors declare no conflict of interest.

\section{References}

1. Zhou, Z.P. China's Rural Population Hollowizing and Its Challenge. Popul. Res. 2008, 32, 45-52.

2. Sheng, Y.N. Family Migration Pattern in China. Popul. Res. 2014, 38, 41-54.

3. Guo, X.M. Researches on the China's Rural Vitalization Strategy from Several Dimensions. Reform 2018, $289,54-61$.

4. Vaugeois, N.; Parker, P.; Yang, Y. Is leisure research contributing to sustainability? A systematic review of the literature. Leisure Loisir 2017, 41, 297-322. [CrossRef]

5. Crompton, J.L. Empirical Evidence of the Contributions of Leisure Services to Alleviating Social Problems: A Key to Repositioning the Leisure Services Field. World Leis. J. 2008, 50, 243-258. [CrossRef]

6. Neo, H. Sustaining the unsustainable? Golf in urban Singapore. Int. J. Sustain. Dev. World Ecol. 2001, 8, 191-202. [CrossRef]

7. Qian, J.; Shen, H.; Law, R.; Chau, K.Y.; Wang, X. Examination of Chinese Tourists' Unsustainable Food Consumption: Causes and Solutions. Sustainability 2019, 11, 3475. [CrossRef]

8. Brightbill, C.K. The Challenge of Leisure; Prentice-Hall: Englewood Cliffs, NJ, USA, 1960.

9. Dumazedier, J. Leisure and the social system. In Concepts of Leisure; Murphy, J.F., Ed.; Prentice-Hall: Englewood Cliffs, NJ, USA, 1974; pp. 129-144.

10. De Grazia, S. Of Time, Work, and Leisure; Anchor Books: Garden City, NY, USA, 1964.

11. Stebbins, R. When leisure engenders health: Fragile effects and precautions. Ann. Leis. Res. 2021, 24, 430-444. [CrossRef]

12. Spracklen, K.; Lashua, B.; Sharpe, E.; Swain, S. (Eds.) Introduction to the Palgrave Handbook of Leisure Theory. In The Palgrave Handbook of Leisure Theory; Palgrave Macmillan: London, UK, 2017; Volume 6, pp. 1-11.

13. Kelly, J.R. Work and Leisure: A Simplified Paradigm. J. Leis. Res. 2009, 41, 439-451. [CrossRef]

14. Stebbins, R.A. Leisure as not work: A (far too) common definition in theory and research on free-time activities. World Leis. J. 2018, 60, 255-264. [CrossRef]

15. Purrington, A.; Hickerson, B. Leisure as a cross-cultural concept. World Leis. J. 2013, 55, 125-137. [CrossRef]

16. Spracklen, K. Constructing Leisure: Historical and Philosophical Debates; Palgrave MacMillan: New York, NY, USA, 2011.

17. Godbey, G. Leisure in Your Life: An Exploration; Venture Publishing Inc.: State College, PA, USA, 1985.

18. Guan, J.; Gao, J.; Zhang, C. Food Heritagization and Sustainable Rural Tourism Destination: The Case of China's Yuanjia Village. Sustainability 2019, 11, 2858. [CrossRef]

19. Kellison, T.B.; Hong, S. The adoption and diffusion of pro-environmental stadium design. Eur. Sport Manag. Q. 2015, 15, 249-269. [CrossRef]

20. McCullough, B.P.; Orr, M.; Kellison, T. Sport Ecology: Conceptualizing an Emerging Subdiscipline Within Sport Management. J. Sport Manag. 2020, 34, 509-520. [CrossRef]

21. Mallen, C.; Adams, L.; Stevens, J.; Thompson, L. Environmental Sustainability in Sport Facility Management: A Delphi Study. Eur. Sport Manag. Q. 2010, 10, 367-389. [CrossRef]

22. McCullough, B.P.; Orr, M.; Watanabe, N.M. Measuring Externalities: The Imperative Next Step to Sustainability Assessment in Sport. J. Sport Manag. 2020, 34, 393-402. [CrossRef]

23. Orr, M.; Inoue, Y. Sport versus climate: Introducing the climate vulnerability of sport organizations framework. Sport Manag. Rev. 2018, 22, 452-463. [CrossRef]

24. Trendafilova, S.; McCullough, B.P. Environmental sustainability scholarship and the efforts of the sport sector: A rapid review of literature. Cogent Soc. Sci. 2018, 4, 1467256. [CrossRef]

25. Brundtland, G.H. Report of the World Commission on Environment and Development: Our Common Future. 20 March 1987. Available online: https://sustainabledevelopment.un.org/content/documents/5987our-common-future.pdf (accessed on 18 July 2020).

26. Jiang, S.J.; Luo, P. A Literature Review on Hollow Villages in China. Chin. J. Popul. Resour. Environ. 2014, 24, 51-58.

27. Sun, H.; Liu, Y.; Xu, K. Hollow villages and rural restructuring in major rural regions of China: A case study of Yucheng City, Shandong Province. Chin. Geogr. Sci. 2011, 21, 354-363. [CrossRef]

28. Liu, Y.S.; Liu, Y.; Zhai, R.X. Geographical Research and Optimizing Practice of Rural Hollowing in China. Acta Geogr. Sin. 2009, 64, 1193-1202.

29. Cui, W.G.; Li, Y.R.; Liu, Y.S. Rural hollowing in key agricultural areas of China: Characteristics, mechanisms and countermeasures. Resour. Sci. 2011, 33, 2014-2021.

30. Liu, Y.S. Research on the urban-rural integration and rural revitalization in the new era in China. Acta Geogr. Sin. 2018, 73, 637-650.

31. Zhang, T.; Wang, Y.L.; Liu, Y.X.; Zhao, M.Y. Establishing an economic insurance system under a multiple dynamic evolution mechanism after rural hollowing renovation. Resour. Sci. 2016, 38, 799-813. 
32. Song, W.; Chen, B.; Zhang, Y. Typical survey and analysis on influencing factors of village-hollowing of rural housing land in China. Geogr. Res. 2013, 32, 20-28.

33. Opinions on Comprehensive Revitalization of the Rural and The Acceleration of Modernization in the Rural Agricultural Sector. Available online: http:/ / www.gov.cn/zhengce/2021-02/21/content_5588098.htm (accessed on 21 August 2021).

34. Hediger, W. Reconciling "weak" and "strong" sustainability. Int. J. Soc. Econ. 1999, 26, 1120-1144. [CrossRef]

35. Shi, L.; Han, L.; Yang, F.; Gao, L. The Evolution of Sustainable Development Theory: Types, Goals, and Research Prospects. Sustainability 2019, 11, 7158. [CrossRef]

36. Neumayer, E. Weak Versus Strong Sustainability: Exploring the Limits of Two Opposing Paradigms; Edward Elgar Publishing: Cheltenham, UK, 2013.

37. Jenkins, W. Sustainability theory. In Berkshire Encyclopedia of Sustainability: The Spirit of Sustainability; Jenkins, W., Ed.; Berkshire: Great Barrington, MA, USA, 2009; pp. 380-384.

38. Cabello, J.M.; Navarro-Jurado, E.; Thiel-Ellul, D.; Rodríguez-Díaz, B.; Ruiz, F. Assessing environmental sustainability by the double reference point methodology: The case of the provinces of Andalusia (Spain). Int. J. Sustain. Dev. World Ecol. 2020, 28, 4-17. [CrossRef]

39. Sen, A. The Ends and Means of Sustainability. J. Hum. Dev. Capab. 2013, 14, 6-20. [CrossRef]

40. Chen, X.; Wu, J. Sustainable landscape architecture: Implications of the Chinese philosophy of "unity of man with nature" and beyond. Landsc. Ecol. 2009, 24, 1015-1026. [CrossRef]

41. Chio, J. Rendering rural modernity: Spectacle and power in a Chinese ethnic tourism village. Crit. Anthropol. 2017, 37, 418-439. [CrossRef]

42. Weng, S.; Peng, H. Tourism development, rights consciousness and the empowerment of Chinese historical village communities. Tour. Geogr. 2014, 16, 772-784. [CrossRef]

43. Gold, R.L. Roles in Sociological Field Observations. Soc. Forces 1958, 36, 217-223. [CrossRef]

44. Greenbaum, T. The Handbook for Focus Group Research, 2nd ed.; Sage Publications: Thousand Oaks, CA, USA, 1998.

45. Braun, V.; Clarke, V. Using thematic analysis in psychology. Qual. Res. Psychol. 2006, 3, 77-101. [CrossRef]

46. Clarke, V.; Braun, V. Using thematic analysis in counselling and psychotherapy research: A critical reflection. Couns. Psychother. Res. 2018, 18, 107-110. [CrossRef]

47. Lei, N.; Han, J.; Mu, X.; Sun, Z.; Wang, H. Effects of improved materials on reclamation of soil properties and crop yield in hollow villages in China. J. Soils Sedim. 2019, 19, 2374-2380. [CrossRef]

48. Zhang, Q.F.; Oya, C.; Ye, J. Bringing Agriculture Back in: The Central Place of Agrarian Change in Rural China Studies. J. Agrar. Chang. 2015, 15, 299-313. [CrossRef] 